\title{
Three-dimensionally phosphatized meiofaunal bivalved arthropods from the Upper Cambrian of Western Hunan, South China
}

\author{
Huaqiao Zhang and Shuhai Xiao
}

With 7 figures

\begin{abstract}
Meiofaunas are important ecological players in modern marine ecosystems, but their Cambrian fossil record is rather poor, even in some of the best-known Lagerstätten, such as the Burgess Shale biota, which are typically dominated by macroscopic animals. In this regard, the Upper Cambrian Wangcun Lagerstätte in South China is unusual in its richness in meiofaunal animals. Here, we described new material of three-dimensionally phosphatized meiofaunal bivalved arthropods from a single horizon in the Paibian Stage, Furongian Series of Wangcun section, Western Hunan, South China. New bivalved arthropods include Albrunnicola bengtsoni (bradoriid), Mengdongella elliptica gen. et sp. nov., and an indeterminate phosphatocopine Gen. et sp. indet. The new discovery extends the stratigraphic and geographic ranges of $A$. bengtsoni, which was previously only known from Lower Cambrian strata of Australia and Antarctic. The shield of A. bengtsoni bears pits that might have facilitated respiration or sensing. Mengdongella elliptica is a new bivalved arthropod of uncertain affinity, with antero-dorsal spines functioning as sensory organs. These new findings highlight the importance of the Orsten-type taphonomic window in revealing the diversity of meiofaunal ecdysozoans in Cambrian oceans.
\end{abstract}

Key words: Orsten-type preservation, bivalved arthropods, meiofauna, Paibian Stage, Furongian Series, Wangcun Lagerstätte, South China.

\section{Introduction}

Ecdysozoan animals (AguinaLDo et al. 1997) have a reasonably good fossil record because of their recalcitrant cuticles that are resistant to taphonomic decay. In Cambrian Konservat-Lagerstätten with exceptionally preserved fossils, for example Burgess Shale-type Lagerstätten, ecdysozoan animals are with no doubt the most abundant and diverse (CONWAY MORRIS 1986; Zhнo et al. 2010, 2014). In typical Burgess Shale-type Lagerstätten, such as the Early Cambrian Chengjiang biota (Hou et al. 2004; CHEN 2004) and the Middle Cambrian Burgess Shale biota (Gould 1989; BRIGGs et al. 1994), macroscopic animals are dominant and they are typically preserved in flattened two-dimensional manners (GAINES et al. 2008). In contrast, Orsten-type Lagerstätten tend to preserve microscopic (generally between $100 \mu \mathrm{m}$ and $2 \mathrm{~mm}$ ) and cuticle-bearing ecdysozoans in three dimensions through the impregnation or encrustation of cuticles by calcium-phosphate (Müller \& Walossek 1985, 1991; MaAs et al. 2006). Hence, Orsten-type fossils, along with small carbonaceous fossils (SCFs; HARVEY \& ButTERFIELD 2008, 2016; Butterfield \& Harvey 2011; Harvey \& Pedder 2013; Harvey et al. 2012a, b), complement typical Burgess Shale-type Lagerstätten and provide a rare window onto meiofaunal ecdysozoans in Cambrian oceans.

Orsten-type Lagerstätten are important because they capture microscopic ecdysozoans that are rare in classical Burgess Shale-type Lagerstätten. For ex- 

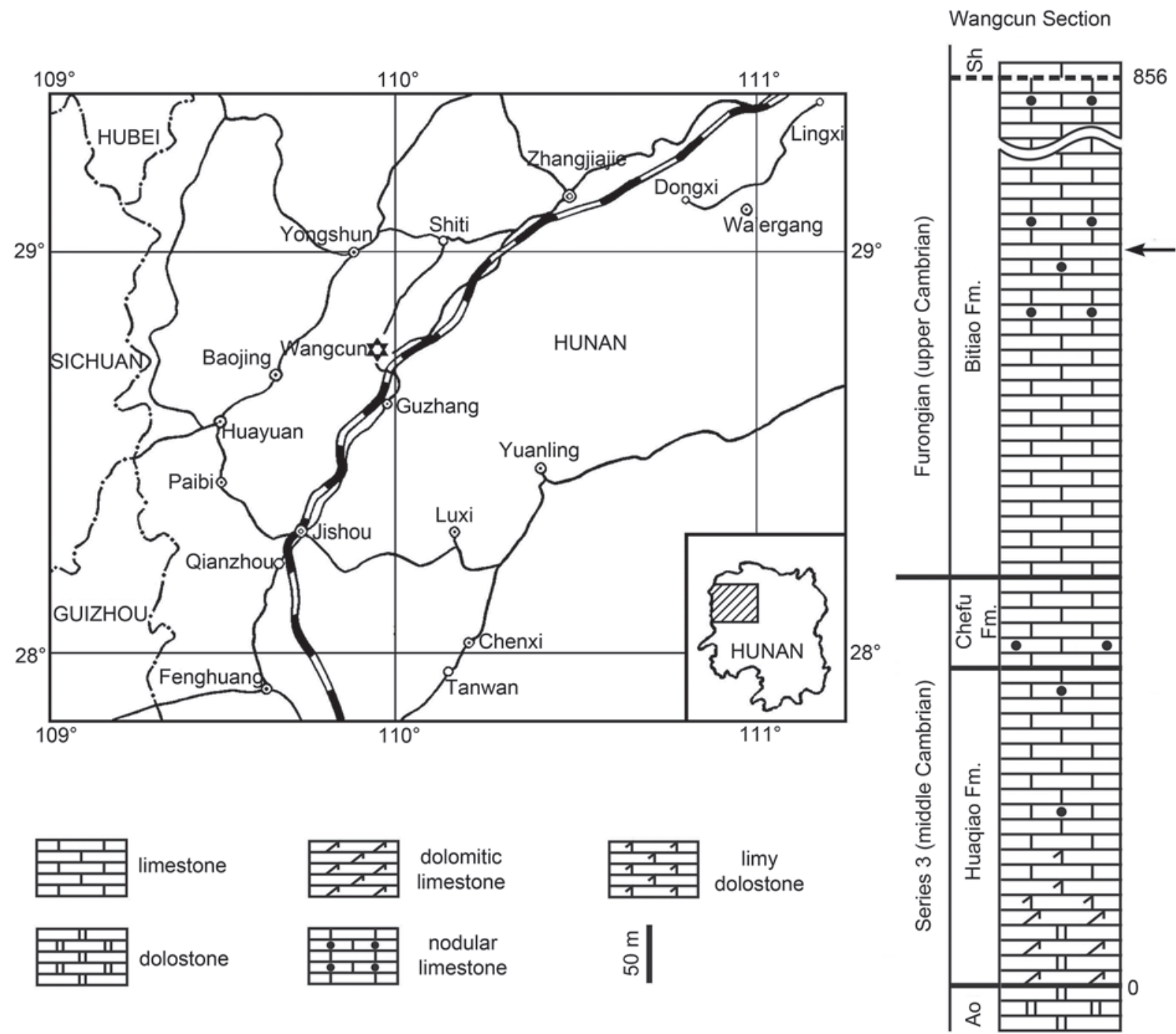

Fig. 1. Location map and stratocolumn of the Wangcun section in Western Hunan, South China. The key fossil horizon yielding the present material is denoted by an arrow, about $650 \mathrm{~m}$ above the base of the Huaqiao Formation. Ao, Aoxi Formation; Sh, Shenjiawan Formation. Revised from Dong et al. (2005a).

ample, there are no convincing crustaceans in classical Burgess Shale-type Lagerstätten, although meiofaunal crustaceans are abundant and diverse in the Orstentype Lagerstätten (MAAS et al. 2006) and small carbonaceous fossil assemblages (HARVEY \& BUTTERFIELD 2008; Butterfield \& Harvey 2011; Harvey \& PedDER 2013; HARVEY et al. 2012a, b). As another example, some of the oldest known cycloneuralian fossils are found in Orsten-type preservation (LiU et al. 2014; ZhANG et al. 2015; SHAO et al. 2016), and these fossils provide key insights into the origin and early divergence of cycloneuralians and ecdysozoans. Thus, Orsten-type
Lagerstätten (or, in general, three-dimensionally phosphatized biotas) need to be scrutinized very closely to uncover the Cambrian diversification of ecdysozoans, particularly if many early ecdysozoans may have been meiofaunal (HARVEY \& BUTTERFIELD 2016).

Here, we describe new three-dimensionally phosphatized bivalved arthropods from Paibian Stage (Upper Cambrian) of Wangcun section in Western Hunan Province of South China. The new material represents part of a Cambrian meiofauna dominated by ecdysozoans and inarticulate brachiopods. 


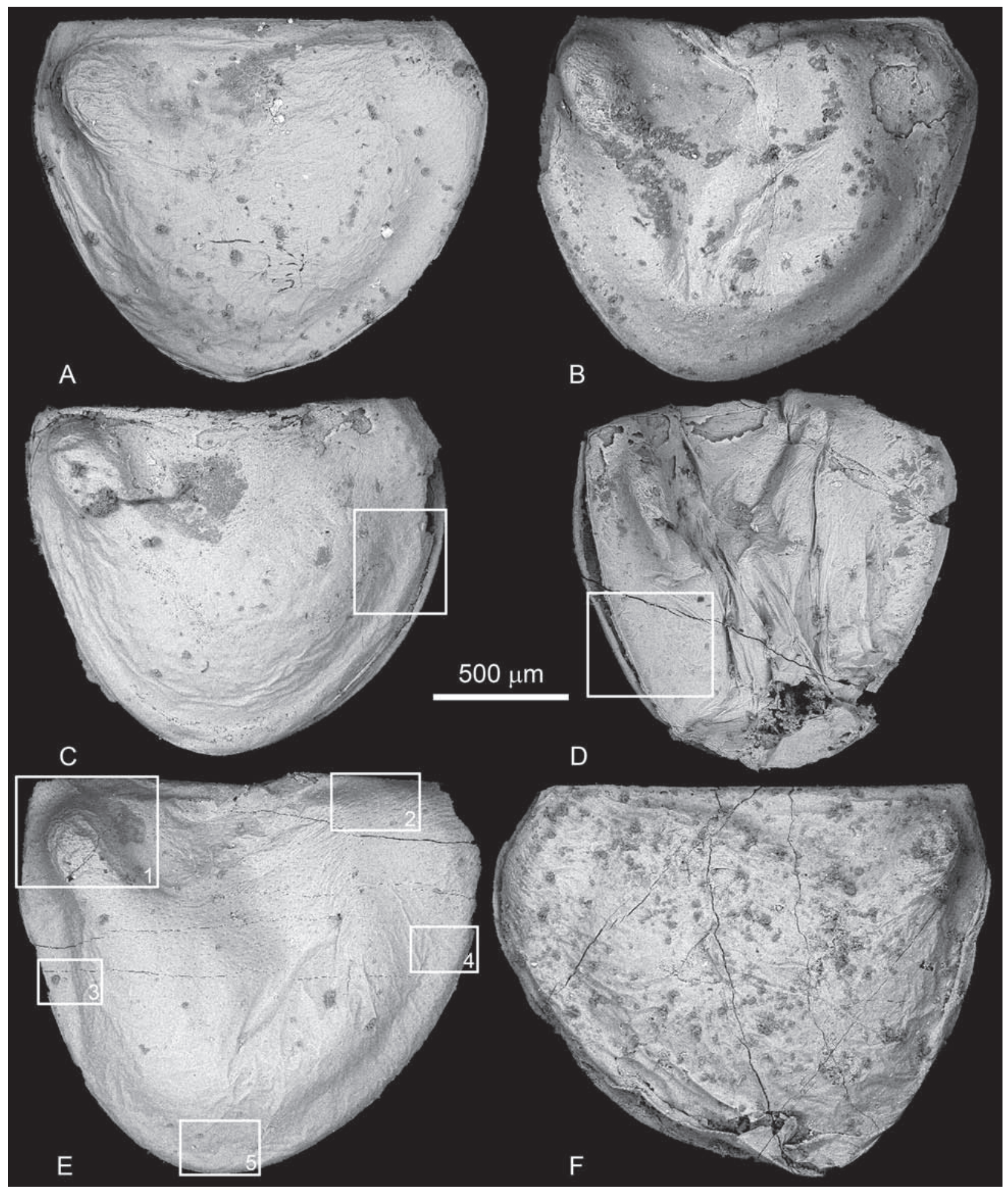

Fig. 2. A-F - Albrunnicola bengtsoni Hinz-Schallreuter, 1993 from the Upper Cambrian of Wangcun section. A, NIGP160499, left lateral view; B, NIGP165204, left lateral view; C, NIGP165191, left lateral view, area in rectangle is enlarged in Fig. 3A; D, NIGP165192, left lateral view, area in rectangle is enlarged in Fig. 3B; E, NIGP165189, left lateral view, areas in rectangles 1 to 5 are enlarged in Fig. 3C-G; F, NIGP165190, right lateral view. Scale bar applies to all images. 


\section{Materials and methods}

The specimens illustrated in this paper are housed at Nanjing Institute of Geology and Palaeontology (NIGP), Chinese Academy of Sciences. They were recovered from the Bitiao Formation at Wangcun section, Western Hunan, South China (Fig. 1). The key horizon yielding the present specimens is a thin-bedded and dark gray limestone that occurs $650 \mathrm{~m}$ above the base of the Huaqiao Formation (Fig. 1). Based on conodont biostratigraphy (DONG \& ZHANG 2017), this horizon is part of the conodont Westergaardodina cf. calix-Prooneotodus rotundatus Zone, belonging to the Paibian Stage of the Furongian Series (PENG et al. 2012). This horizon has previously yielded abundant fossil embryos of Markuelia hunanensis (Dong et al. 2004, 2005b, 2010; Dong 2007, 2009), trunk fragments of palaeoscolecids (DUAN et al. 2012; DUAN \& Dong 2013), and a single Type-A larva in Orsten-type preservation (ZHANG et al. 2016).

Rock samples from the key horizon at Wangcun section (Fig. 1) were collected and processed in NIGP. The rock samples were first crushed into walnut-sized pieces $(2-3 \mathrm{~cm}$ in diameter), and then dissolved in acetic acid following procedures described by MülLER (1985). Rock fragments were immersed in diluted acetic acid $(\sim 10 \%)$, and residues were retrieved regularly after three days of reaction in summer (environment temperature around $40{ }^{\circ} \mathrm{C}$ ). The residues were dried naturally, and microfossils were handpicked under an Olympus SZ binocular microscope. We obtained abundant three-dimensionally phosphatized ecdysozoans, including fossil embryos assignable to Markuelia, cuticular fragments of palaeoscolecids, and bivalved arthropods, together with other microfossils such as sponge spicules and abundant inarticulate brachiopods. The current paper focuses on the bivalved arthropods only.

Selected microfossils were mounted on aluminum stubs for observation under an LEO1530VP field-emission environmental scanning electron microscope (SEM) at NIGP, and the figures were processed using Adobe Photoshop CS5.

\section{Systematic palaeontology}

Arthropoda sensu lato sensu MAAs et al., 2004

Phylum Arthropoda v. SieBold, 1848

Class uncertain

Order Bradoriida RAYMOND, 1935

Family Hipponicharionidae Sylvester-Bradley in BENSON, 1961

Genus Albrunnicola MARTinsson, 1979,
Type species: Longispina oelandica ANDRES 1969.

Albrunnicola bengtsoni HinZ-SchALLREUTER 1993

Figs. 2, 3

1986 Hipponicharion sp. - GAZDZICKI \& Wrona, fig. 7e.

1990 Hipponicharion sp. - Bengtson in Bengtson et al., p. 325 , fig. 207A.

1993 Albrunnicola bengtsoni n. sp. - HINZ-SchalLREUTER, p. 424.

2001 Albrunnicola bengtsoni. - MeLniKova in Gravestock et al., p. 210, fig. 26a, b.

2006 Albrunnicola bengtsoni. - SKovsted et al., p. 26, fig. $10 \mathrm{~A}-\mathrm{H}$

2007 Albrunnicola bengtsoni. - TOPPER et al., p. 85, fig. $10 \mathrm{~A}-\mathrm{K}$.

2009 Albrunnicola bengtsoni. - WRONA, p. 357, figs. 5A, B, 6A-D, 7A-D, 8A, B, 9A, B.

2016 Albrunnicola bengtsoni. - BetTs et al., p. 198, fig. 20G, H.

Material: Six specimens, NIGP160499, 165189-165192, and 165204.

Description: Bivalved bradoriids. Shields are inverted triangular in lateral profile. The dorsal line is straight (Fig. $2 \mathrm{~A}, \mathrm{C}, \mathrm{F})$, with a single dorsal furrow demarcating the right and left valves. The shield has slight anterior and posterior swings, thus it is longest slightly ventral to the dorsal line. The valves are highest at or slightly anterior to the anteriorposterior midline (am-plete or slightly pre-plete). The anterior lobe is strong (Fig. 3C), with the inflation extending first postero-ventrally and then postero-dorsally. The marginal rim is weak (Fig. 3A, B), and the duplicature is relatively narrow and extends along the whole inner margin of the valves (Fig. 3A, B). The valve surface is ornamented with imbricated pits with lateral wings (Fig. 3). The pits are more concentrated at the anterior, posterior, middle, and dorsal parts of the valves (Fig. 3C, D, E, G), and relatively sparse at the ventral part (Fig. 3F). The angular bisectors of the angles of the two lateral wings point mainly to the mid-dorsal part of the shield (Fig. 3A, B, E, F, G). Internal soft-part anatomy was not preserved.

Measurements: The current specimens are more or less of equal size, possibly representing the same instar. The shield is about $1.7 \mathrm{~mm}$ long and $1.4 \mathrm{~mm}$ high. Anterior lobe is 450 $\mu \mathrm{m}$ in size. The pits are about $2.8 \mu \mathrm{m}$ in diameter, and each lateral wing is about $6.7 \mu \mathrm{m}$ long. The lateral wings form an angle of about $150^{\circ}$.

Fig. 3. A-G - Close-up views of Albrunnicola bengtsoni Hinz-SchallReuter, 1993 from the Upper Cambrian of Wangcun section. A, NIGP165191 (Fig. 2C); B, NIGP165192 (Fig. 2D); C-G, NIGP165189 (Fig. 2E). Scale bar between A and B applies to $\mathrm{A}$ and $\mathrm{B}$, scale bar below $\mathrm{C}$ applies to $\mathrm{C}, \mathrm{D}$, and $\mathrm{F}$, and scale bar to the right of $\mathrm{G}$ applies to $\mathrm{E}$ and $\mathrm{G}$. 


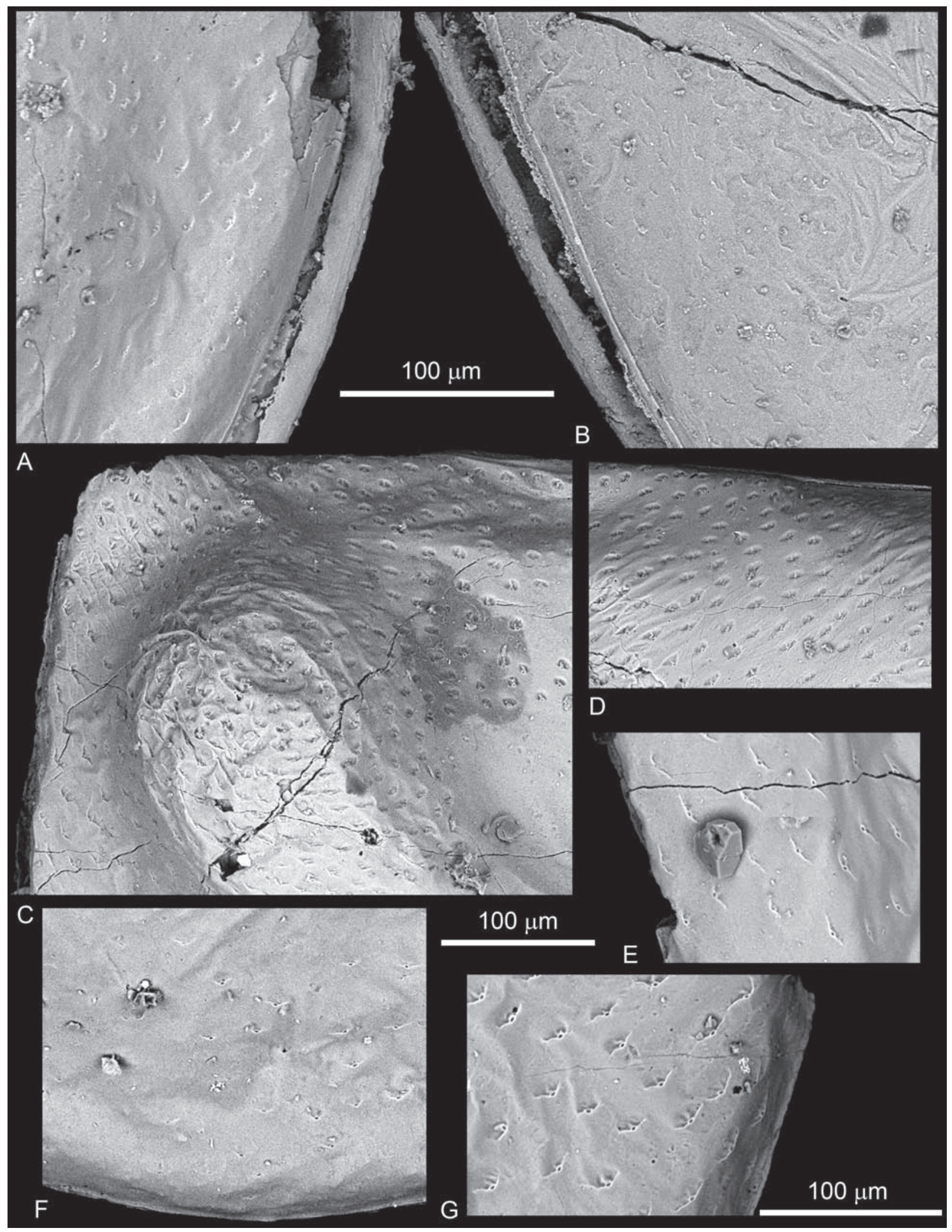

Fig. 3. 


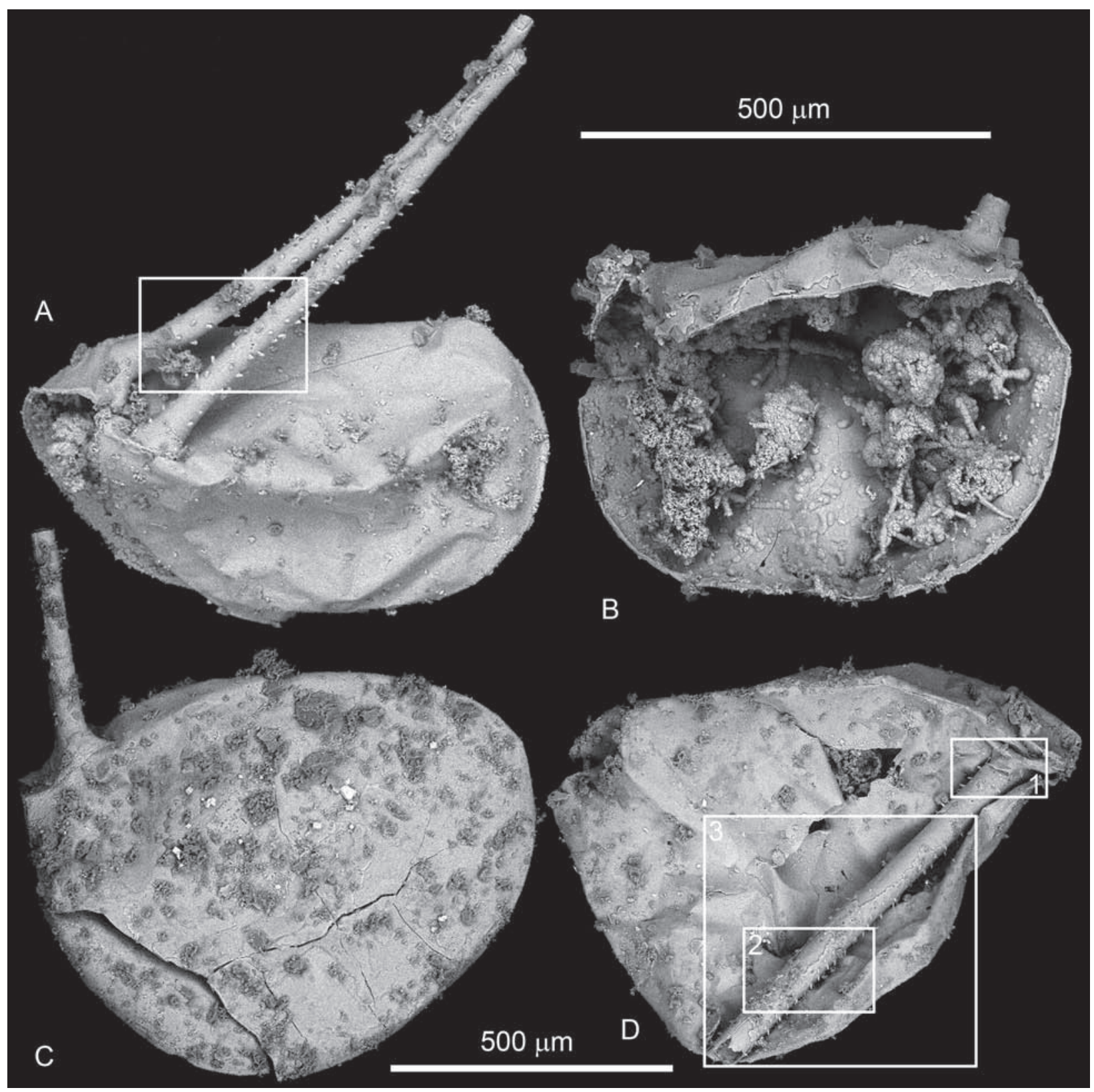

Fig. 4. A-D - Mengdongella elliptica gen. et sp. nov. from the Upper Cambrian of Wangcun section. A, holotype, NIGP165196, left lateral view, area in rectangle is enlarged in Fig. 5A; B, NIGP165205, right lateral view, right valve partly missing; C, NIGP165194, left lateral view; D, NIGP165206, areas in rectangles 1, 2, and 3 are enlarged in Fig. 5B, C, and D, respectively. Scale bar above B applies to A and B, and sclae bar between C and D applies to C and D.

Fig. 5. A-E - Close-up views of Mengdongella elliptica gen. et sp. nov. from the Upper Cambrian of Wangcun section. A, NIGP165196 (Fig. 4A); B, C, E, NIGP165206 (Fig. 4D); D, NIGP165193 (Fig. 6A). 


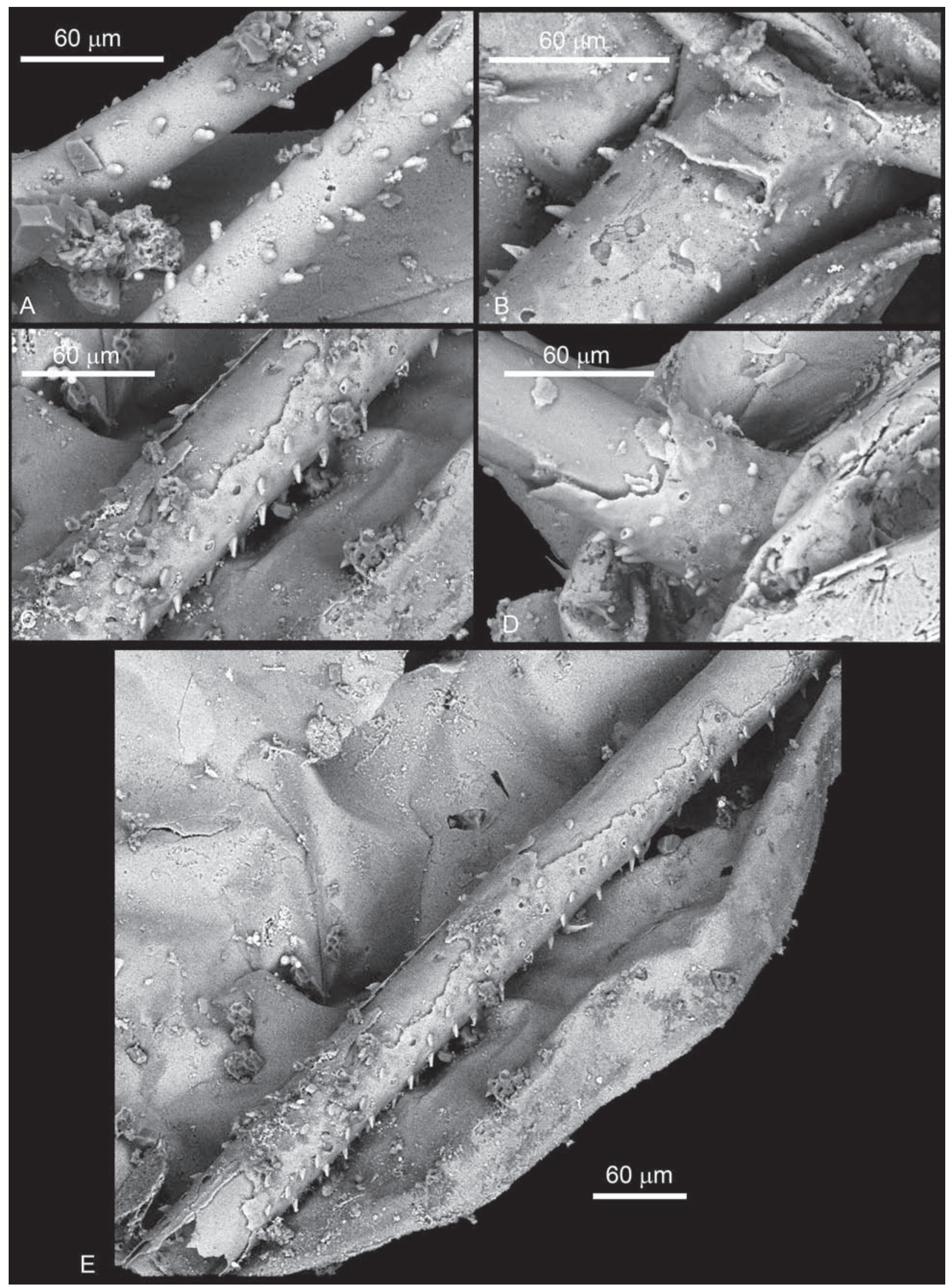

Fig. 5. 


\section{Class, Order, and Family uncertain Genus Mengdongella nov.}

Etymology: With reference to Mengdong River, along which the Wangcun section is exposed.

Type species: Mengdongella elliptica gen. et sp. nov.

Diagnosis: As for the type species.

Occurrence: Conodont Westergaardodina cf. calix-Prooneotodus rotundatus Zone, Bitiao Formation, Furongian (Upper Cambrian); Wangcun section, Yongshun County, Western Hunan, South China.

\section{Mengdongella elliptica gen. et sp. nov. Figs. 4, 5, 6A-D, 7}

Etymology: With reference to the elliptic profile of the shield.

Holotype: NIGP165196 (Fig. 4A).

Material: Eight specimens, NIGP165193-165196, 165205165208 .

Diagnosis: Bivalved arthropods with a shield of elliptic profile; shield slightly pre-plete; duplicature narrow; dorsal line arched; a pair of spines at antero-dorsal position of the valves; spines long, internally hollow, with regularly arranged conical or scale-like structures on the surface.

Description: Mengdongella elliptica is a bivalved arthropod. The two valves are demarcated from each other by a single dorsal furrow (Figs. 4A, 6D). The dorsal line is arched (Figs. 4C, 6A, D), and the valves are thus elliptic in lateral profile. The shield is longest slightly ventral to the dorsal line, and highest slightly anterior to the anterior-posterior midline (pre-plete). The valves are smooth without any structures or ornaments (Fig. 6A, B, D). The duplicature is narrow, extending along the whole inner margins of the valves (Figs. 4B, 6A). A pair of spines are situated at the antero-dorsal position of the valves. The spines are long, exceeding the length of the shield (Figs. 4A, 6D). The surface of the spines is ornamented with small conical (Figs. 5A-E, 7A, B) or scaleshaped (Fig. 7C, D) structures. The conical or scale-shaped structures have slender tips directed adapically 45 degrees to the spines. They are distributed uniformly on the surface of the spines (Figs. 5E, 7A). These structures appear internally hollow (Figs. 5, 7D), but this might be due to secondary coating. The soft-body anatomy within the bivalved shield is not preserved (Fig. 4B).

Measurements: The material of Mengdongella elliptica includes specimens of different sizes and at different ontogenetic stages. Their shields range in length from $640 \mu \mathrm{m}$ (Fig. 4A) to $970 \mu \mathrm{m}$ (Fig. 6D). The spines of the smallest specimen (Fig. 4A) are at least $680 \mu \mathrm{m}$ long, a little longer than the shield length, and those of the largest specimen (Fig.
6D) are at least $1.1 \mathrm{~mm}$, also a little longer than the shield length. The scale-shaped structures of the largest specimen (Fig. 7C) are about $3.5 \mu \mathrm{m}$ wide at base and $6.5 \mu \mathrm{m}$ long, and the conical structures on the smallest specimen (Fig. $5 \mathrm{~A}$ ) are about $6.7 \mu \mathrm{m}$ wide at base and $8.8 \mu \mathrm{m}$ long.

Comparisons: Mengdongella elliptica gen. et sp. nov. bears arched dorsal line, and thus differs from bradoriids, phosphatocopines, and Cambrolongispina ZHANG et al. 2014 that have straight dorsal lines. As bivalved shields convergently evolved among arthropods of distant affinities, the phylogenetic affinity of $M$. elliptica is currently unknown. The antero-dorsal spines can be oriented antero-dorsally (Fig. 6A, B), anteriorly (Fig. 6D), or postero-dorsally (Fig. 4A), probably due to taphonomic distortion of the valves. We infer, on the basis of NIGP165194 (Fig. 4C), that these spines were directed antero-dorsally when alive. Cambrolongispina reticulata ZHANG et al. 2014 also has antero-dorsal spines that are ornamented, but these ornaments are paddle-shaped structures aligned in a single row along the posterior edge of the spines. In contrast, the conical or scale-shaped structures on the spines of M. elliptica are distributed uniformly on the entire surface of the spines.

\section{Class and Order uncertain Suborder Phosphatocopina MÜLLER, 1964}

Gen. et sp. indet.

Fig. 6E

Material: One specimen, NIGP165197.

Description: The bivalved shield, with one end missing, is estimated to be about $800 \mu \mathrm{m}$ long and $350 \mu \mathrm{m}$ high. The completely preserved end is assumed to be anterior. The shield is longest at its dorsal line, and highest slightly anterior to the anterior-posterior midline (pre-plete). The valve surface is smooth without any lobes, spines, or other ornaments.

Remarks: Gen. et sp. indet. lacks key bradoriid characters such as valve lobes. Its shield with smooth valve surface and straight dorsal line is reminiscent of phosphatocopines. Phosphatocopines are abundant in the Upper Cambrian of Sweden (MAAs et al. 2003). At Wangcun, phosphatocopines were also reported from a single horizon about $100 \mathrm{~m}$ below the current horizon (Dong et al. 2005a; ZhANG et al. 2010). In the current horizon, phosphatocopines are relatively rare. The orientation of Gen. et sp. indet. is somewhat ambiguous. The completely preserved end is interpreted to be anterior, consistent with the general orientation of most phosphatocopines, because phosphatocopines generally have am-plete (highest position at anterior-posterior midline) or pre-plete (highest position anterior to anterior-posterior midline) shields (MAAS et al. 2003), while bradoriids generally have post-plete (highest position posterior to anterior-posterior midline) shields (ZHANG 2007). 


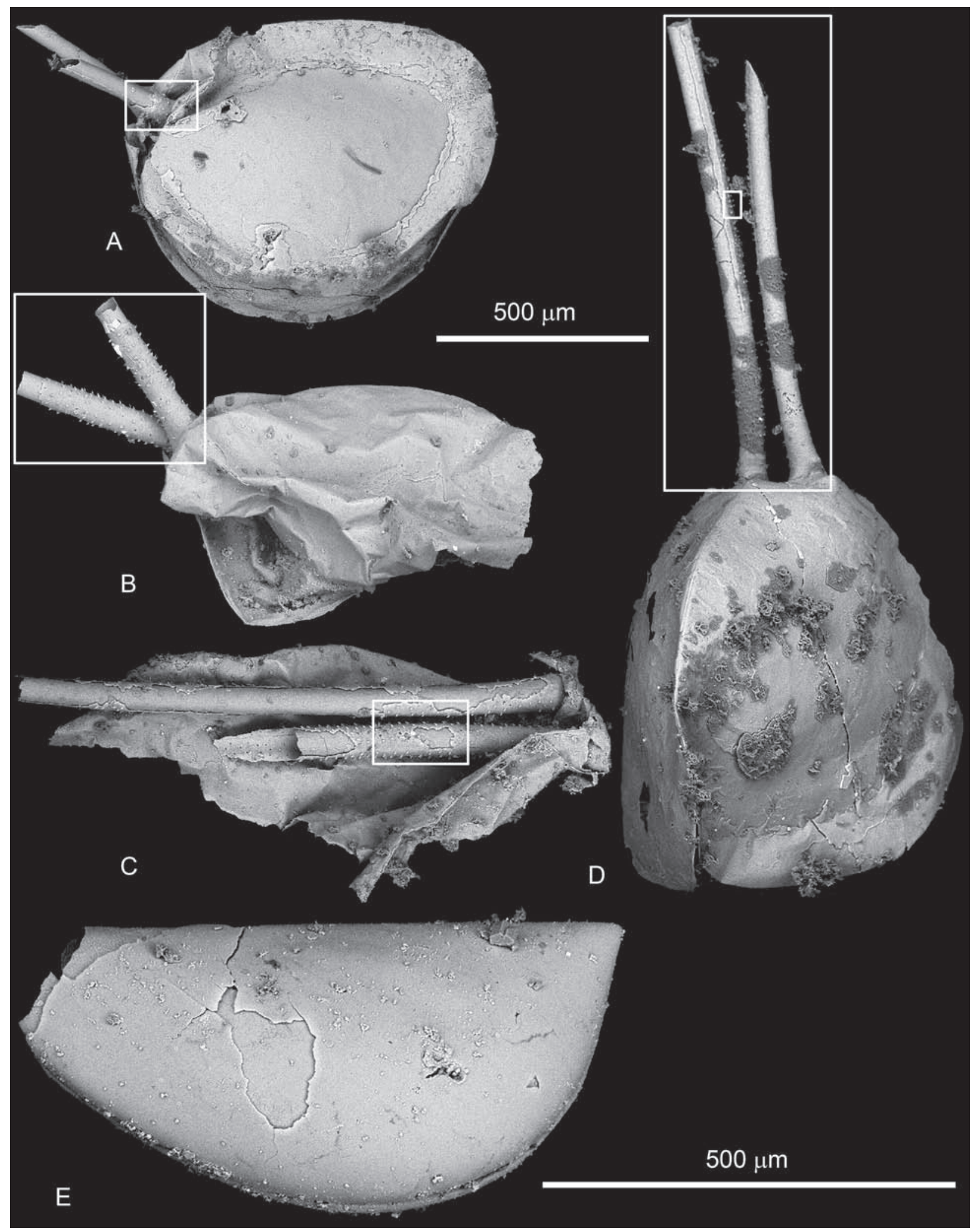

Fig. 6. A-D - Mengdongella elliptica gen. et sp. nov. from the Upper Cambrian of Wangcun section. A, NIGP165193, left lateral view, area in rectangle is enlarged in Fig. 5D; B, NIGP165207, left lateral view, area in rectangle is enlarged in Fig. 7A; C, NIGP165208, a fragment, dorsal view, area in rectangle is enlarged in Fig. 7B; D, NIGP165195, dorsal view, area in small rectangle is enlargd in Fig. 7C, and area in large rectangle is enlarged in Fig. 7D. E - Gen. et sp. indet., same provenance, NIGP165197, right lateral view. Scale bar between A and B applies to A-D, and scale bar to the right of E applies to E only. 


\section{Discussion}

Bradoriids are relatively rare in the Late Cambrian (Williams et al. 2007), but in our collection we have obtained numerous specimens of Albrunnicola bengtsoni. A. bengtsoni was previously reported only from the Early Cambrian of South Australia and Antarctic (Wrona 2009), and the type horizon and locality of $A$. bengtsoni is the Lower Cambrian Parara Limestone, Kulpara Road section, Yorke Peninsula, South Australia (BENGTSON et al. 1990). The current material shows that this species has a long stratigraphic range and wide palaeogeographic distribution. During the Cambrian Period, South China, Australia, and Antarctic were peri-Gondwana continents located around the palaeoequator. The common occurrence of $A$. bengtsoni on these three continents indicates a free exchange of arthropod animals among them.

The pits with lateral wings on the valve surface of Albrunnicola bengtsoni were previously described as small pits (SKOvsTed et al. 2006), "small pits of U- to V-shaped identations" (TOPPER et al. 2007), or crescentic pits (Wrona 2009). Sometimes, the lateral wings of these pits were developed into scales (WRONA 2009). The pits might have housed sensory setae (TOPPER et al. 2007), or might have functioned to enlarge the surface area of the valves in order to facilitate respiration. This type of pits might be convergently evolved in bradoriids of distant affinities, for example, Quadricona madonnae ToPPER et al., 2011 (ToPPER et al. 2011, fig. 6J) and Parahoulongdongella bashanensis SHU, 1990 (TOPPER et al. 2011, fig. 7D). Thus, they are not phylogenetically informative.

We speculate that the spines of both Mengdongella elliptica get. et sp. nov. and Cambrolongispina reticulata may have functioned as sensory organs. The antero-dorsal spines of $M$. elliptica resemble more or less the disassociated sclerites assigned to the form genus Mongolitubulus MissarZHevsKy, 1977, and similar spines have also been reported from the Middle Cambrian Huaqiao Formation at the Wangcun and Paibi sections in Western Hunan (ZHU \& DoNg 2004). Recent studies suggested that Mongolitubulus-like sclerites are convergent rather than homologous structures (Li et al. 2012). For example, some Mongolitubulus-like sclerites may be the spines of eodiscoid trilobites (Li et al. 2012), while others may be the spines of bradoriids (SKOvSTED et al. 2006; TOPPER et al. 2013), or of hallucigeniid lobopodians (CARON et al. 2013). It should be noted that the conical or scale-shaped structures of M. elliptica differ from the scaly sculptures of Mongolitubulus in that the latter are more densely spaced and more regularly distributed. Therefore, the spines of M. elliptica are better not assigned to the form genus Mongolitubulus.

\section{Conclusions}

Three-dimensionally phosphatized bivalved arthropods were recovered from the Paibian Stage, Furongian Series of the Upper Cambrian at the Wangcun section, Western Hunan, South China. These new arthropod fossils include Albrunnicola bengtsoni, Mengdongella elliptica gen. et sp. nov., and an indeterminate phosphatocopine Gen. et sp. indet. Bivalved arthropods from Wangcun are preserved with their shields only, and the lack of anatomic information about their soft-bodied structures hinders their phylogenetic assignment. The new discovery extends the occurrence of $A$. bengtsoni from the Lower Cambrian of Australia and Antarctic to the Upper Cambrian of South China. The pits on the shield of A. bengtsoni may have housed sensory setae, or functioned as respiratory organs to facilitate respiration and gas exchange through the shield. The antero-dorsal spines of M. elliptica may have functioned as sensory organs to detect water currents and preys/predators nearby, and the conical or scale-shaped structures on the spines may also be related to the sensory function.

\section{Acknowledgements}

This work was supported by the Chinese Ministry of Science and Technology 973 Project (2013CB837100 to HZ), the National Natural Science Foundation of China (41572007 to HZ), the US National Science Foundation (EAR 1528553 to SX), and the Youth Innovation Promotion Association, Chinese Academy of Sciences (2016283 to HZ). PhILIP C.J. Donoghue (University of Bristol, UK) and an anonymous reviewer provided constructive comments to this paper. We thank XI-PING Dong (Peking University, Beijing) for field assistance, MARK WILLIAMS (University of Leicester, UK) and Shanchi Peng (NIGP, Nanjing) for discussions.

Fig. 7. A-D - Close-up views of Mengdongella elliptica gen. et sp. nov. from the Upper Cambrian of Wangcun section. A, NIGP165207 (Fig. 6B); B, NIGP165208 (Fig. 6C); C, D, NIGP165195 (Fig. 6D). 


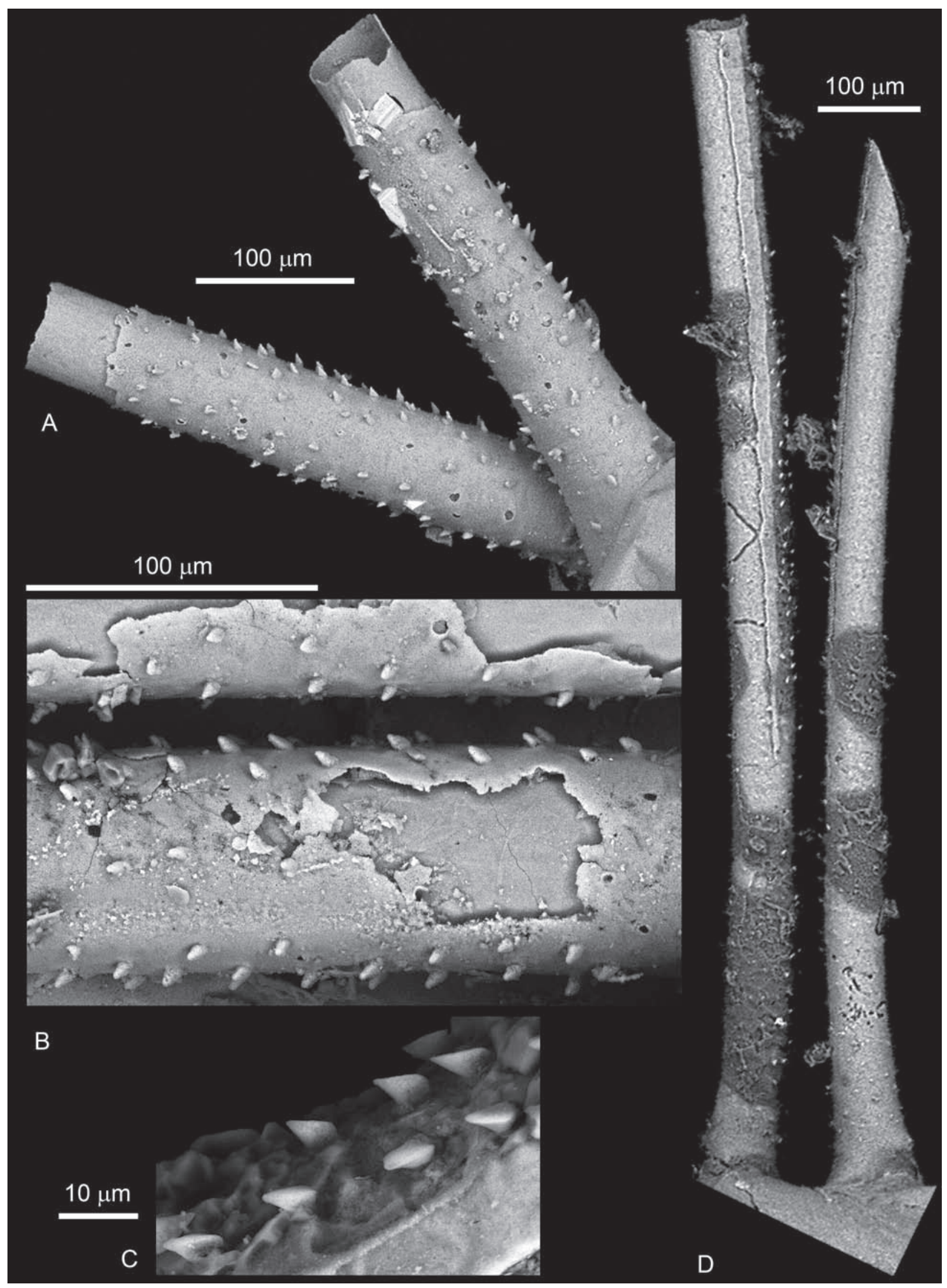

Fig. 7. 


\section{References}

Aguinaldo, A.M.A., Turbeville, J.M., Linford, L.S., RiveRA, M.C., Garey, J.R., RAFF, R.A. \& LAKe, J.A. (1997): Evidence for a clade of nematodes, arthropods and other moulting animals. - Nature, 387: 489-493.

AndREs, D. (1969): Ostracoden aus dem mittleren Kambrium von Öland. - Lethaia, 2: 165-180.

Bengtson, S., Conway Morris, S., Cooper, B.J., Jell, P.A. \& Runnegar, B.N. (1990): Early Cambrian Fossils from South Australia. - Memoirs of the Association of Australian Palaeontologists, 9: 364 pp.; Brisbane (Association of Australian Palaeontologists).

Benson, R.H. (1961): Systematic description. - In: Moore R.C. \& Pitrat C.W. (Eds.): Treatise on Invertebrate Paleontology: 99-421; Lawrence (University of Kansas Press \& Geological Society of America).

Betts, M.J., Paterson, J.R., Jago, J.B., Jacquet, S.M., SkovSted, C.B., Topper, T.P. \& Brock, G.A. (2016): A new Lower Cambrian shelly fossil biostratigraphy for South Australia. - Gondwana Research, 36: 176-208.

Briggs, D.E.G., Erwin, D.H. \& Collier, F.J. (1994): The Fossils of the Burgess Shale. - 238 pp.; Washington (Smithsonian Institution Press).

Butterfield, N.J. \& Harvey, T.H.P. (2011): Small carbonaceous fossils (SCFs): A new measure of early Paleozoic paleobiology. - Geology, 40: 71-74.

Caron, J.-B., Smith, M.R. \& Harvey, T.H.P. (2013): Beyond the Burgess Shale: Cambrian microfossils track the rise and fall of hallucigeniid lobopodians. - Proceedings of the Royal Society, (B), 280: 20131613.

Chen, J. (2004): The Dawn of Animal World. - 366 pp.; Nanjing (Jiangsu Science \& Technology Press).

Conway Morris, S. (1986): The community structure of the Middle Cambrian Phyllopod bed (Burgess Shale). - Palaeontology, 29: 423-467.

Dong, X.-P. (2007): Developmental sequence of Cambrian embryo Markuelia. - Chinese Science Bulletin (English Edition), 52: 929-935.

Dong, X.-P. (2009): Cambrian fossil embryos from Western Hunan, South China. - Acta Geologica Sinica (English Edition), 83: 429-439.

Dong, X.-P., Bengtson, S., Gostling, N.J., Cunningham, J.A., Harvey, T.H.P., Kouchinsky, A., Val'Kov, A.K., Repetski, J.E., Stampanoni, M., Marone, E. \& Donoghue, P.C.J. (2010): The anatomy, taphonomy, taxonomy and systematic affinity of Markuelia: Early Cambrian to Early Ordovician scalidophorans. - Palaeontology, 53: 1291-1314.

Dong, X.-P., Donoghue, P.C.J., Cheng, H. \& Liu, J.-B. (2004): Fossil embryos from the Middle and Late Cambrian period of Hunan, south China. - Nature, 427: 237-240.

Dong, X.-P., Donoghue, P.C.J., Liu, Z., Liu, J. \& Peng, F. (2005a): The fossils of Orsten-type preservation from Middle and Upper Cambrian in Hunan, China - Threedimensionally preserved soft-bodied fossils (Arthropods). - Chinese Science Bulletin (English Edition), 50: 1352-1357.

Dong, X.-P, Donoghue, P.C.J., Cunningham, J.A., Liu, J. \& Cheng, H. (2005b): The anatomy, affinity, and phylogenetic significance of Markuelia. - Evolution \& Development, 7: 468-482.
Dong, X.-P. \& Zhang, H.Q. (2017): Middle Cambrian through lowermost Ordovician conodonts from Hunan, South China. - Journal of Paleontology, 91: 1-89.

DuAn, B.C. \& Dong, X.-P. (2013): Furongian (Late Cambrian) palaeoscolecid cuticles from Hunan Province, South China: the growth impact on the worm cuticle. - Acta Scientiarum Naturalium Universitatis Pekinensis, 49: 591-602.

Duan, B., Dong, X.-P. \& Donoghue, P.C.J. (2012): New palaeoscolecid worms from the Furongian (Upper Cambrian) of Hunan, South China: Is Markuelia an embryonic palaeoscolecid? - Palaeontology, 55: 613-622.

Gaines, R.R., Briggs, E.G. \& ZhaO, Y. (2008): Cambrian Burgess Shale-type deposits share a common mode of fossilization. - Geology, 36: 755-758.

GazDZicki, A. \& Wrona, R. (1986): Polskie badania paleontologiczne w Antarktyce Zachodniej (1986). - Prezglad Geologiczny, 34: 609-617.

Gould, S.J. (1989): Wonderful Life: The Burgess Shale and the Nature of History. - 347 pp.; New York (Norton).

Gravestock, D.I., Alexander, E.M., Demidenko, Y.E., Esakova, N.V., Holmer, L.E., JaGo, J.B., Lin, T.R., Melnikova, L.M., Parkhaev, P.Y., Rozanov, A.Y., Ushatinskaya, G.T., ZANG, W.L, Zhegallo, E.A. \& Zhuravlev, A.Y. (2001): The Cambrian biostratigraphy of the Stansbury Basin, South Australia. - Transactions of the Palaeontological Institute, 282: 1-343.

Harvey, T.H.P. \& Buttefield, N.J. (2008): Sophisticated particle-feeding in a large Early Cambrian crustacean. - Nature, 452: 868-871.

Harvey, T.H.P. \& Buttefield, N.J. (2016): Exceptionally preserved Cambrian loriciferans and the early animal invasion of the meiobenthos. - Nature Ecology \& Evolution, 1: 0022.

Harvey, T.H.P., Ortega-Hernández, J., Lin, J.P., Zhao, Y.L. \& Butterfield, N.J. (2012a): Burgess Shale-type microfossils from the Middle Cambrian Kaili Formation, Guizhou Province, China. - Acta Palaeontologica Polanica, 57: 423-436.

Harvey, T.H.P. \& Pedder, B.E. (2013): Copepod mandible palynomorphs from the Nolichucky Shale (Camrian, Tennessee): Implications for the taphonomy and recovery of small carbonaceous fossils. - Palaios, 28: 278-284.

Harvey, T.H.P., Vélez, M.I. \& Butterfild, N.J. (2012b): Exceptionally preserved crustaceans from Western Canada reveal a cryptic Cambrian radiation. - Proceedings of the National Academy of Sciences of the United States of America, 109: 1589-1594.

Hinz-Schallreuter, I. (1993): Cambrian ostracodes mainly from Baltoscandia and Morocco. - Archiv für Geschiebekunde, 1: 369, 370, 385-448.

Hou, X., Aldridge, R.J., Bergström, J., Siveter, D.J., SivetER, D.J. \& WANG, H. (2004): The Cambrian Fossils of Chengjiang, China: The Flowering of Early Animal Life. - 233 pp.; Oxford (Blackwell).

Li, G.X., Steiner, M., Zhu, M.Y. \& Zhao, X. (2012): Early Cambrian eodiscoid trilobite Hupeidiscus orientalis from South China: ontogeny and implications for affinities of Mongolitubulus-like sclerites. - Bulletin of Geosciences, 87: 159-169.

Liu, Y.H., Xiao, S., Shao, T.Q., Broce, J. \& Zhang, H.Q. 
(2014): The oldest known priapulid-like scalidophoran animal and its implications for the early evolution of cycloneuralians and ecdysozoans. - Evolution \& Development, 16: 155-165.

Müller, K.J. (1964): Ostracoda (Bradorina) mit phosphatischen Gehäusen aus dem Oberkambrium von Schweden. - Neues Jahrbuch für Geologie und Paläontologie, Abhandlungen, 121: 1-46.

MüLlER, K.J. (1985): Exceptional preservation in calcareous nodules. - Philosophical Transactions of the Royal Society of London, (B), 311: 67-73.

MÜller, K.J. \& WAlosseK, D. (1985): A remarkable arthropod fauna from the Upper Cambrian "Orsten" of Sweden. - In: Bowes, D.R. \& WATERStOn, C.D. (Eds.): Fossil arthropods as living animals: 161-172; Edinburgh (Royal Society of Edinburgh).

MülleR, K.J. \& WalosseK, D. (1991): 'Orsten' arthropods - small in size but of great impact on biological and phylogenetic interpretations. - GFF, 113: 88-90.

Maas, A., Braun, A., Dong, X.-P., Donoghue, P.C.J., MülLer, K.J., Olempska, E., RePetski, J.E., Siveter, D.J., Stein, M. \& Waloszer, D. (2006): The 'Orsten' - More than a Cambrian Konservat-Lagerstätte yielding exceptional preservation. - Palaeoworld, 15: 266-282.

MaAs, A., Waloszek, D., Chen, J.Y., Braun, A., Wang, X.Q. \& HuAng, D.Y. (2004): Phylogeny and life habits of early arthropods - predation in the Early Cambrian sea. - Progress in Natural Science, 14: 158-166.

MaAs, A., WaloszeK, D. \& Müller, K.J. (2003): Morphology, ontogeny and phylogeny of the Phosphatocopina (Crustacea) from the Upper Cambrian 'Orsten' of Sweden. - Fossils and Strata, 49: 1-238.

Martinsson, A. (1979): Albrunnicola, a new name for the Cambrian ostracode genus Longispina ANDRES 1969. Lethaia, 12: 27.

MissarzheVsKy, V.V. (1977): Konodonty (?) i fosfantnye problematiki kembriya Mongolii i Sibiri [Conodonts (?) and phosphatic problematica from the Cambrian of Mongolia and Siberia]. - In: TATARInov, L.P. (Ed.): Bespozvonochnye Paleozoya Mongolii: 10-19; Nauka, Moscow (Trudy Sovmestaya Sovetsko-Mongolskaya Paleonotologicheskaya Ekspeditsiya).

Peng, S., Babcock, L.E. \& Cooper, R.A. (2012): The Cambrian Period. - In: Gradstein, F.M., OGG, J.G., Schmitz, M. \& OGG, G. (Eds.): Geological Time Scale 2012: 437488; Oxford (Elsevier).

RAYMOND, P.E. (1935): Leanchoilia and other Mid-Cambrian Arthropoda. - Bulletin of the Museum of Comparative Zoology, 76: 205-230.

ShaO, T.Q., LiU, Y.H., WANG, Q., Zhang, H.Q., TANG, H.H. \& LI, Y. (2016): New material of the oldest known scalidophoran animal Eopriapulites sphinx. - Palaeoworld, 25: $1-11$.

Siebold, C.T. v. (1848): Lehrbuch der vergleichenden Anatomie der Wirbellosen Thiere. Erster Theil. - 679 pp.; Berlin (Veit \& Co.).

Skovsted, C.B., Brock, G.A. \& Paterson, J.R. (2006): Bivalved arthropods from the Lower Cambrian Mernmerna Formation, Arrowie Basin, South Australia and their implications for identification of Cambrian 'small shelly fossils'. - Memoirs of the Association of Australasian
Palaeontologists, 32: 7-41.

Topper, T.P., Skovsted, C.B., Brock, G.A. \& Paterson, J.R. (2007): New bradoriids from the lower Cambrian Mernmerna Formation, South Australia: systematics, biostratigraphy and biogeography. - Memoirs of the Association of Australasian Palaeontologists, 33: 67-100.

Topper, T.P., Skovsted, C.B., Brock, G.A. \& PAterson, J.R. (2011): The oldest bivalved arthropods from the early Cambrian of East Gondwana: Systematics, biostratigraphy and biogeography. - Gondwana Research, 19: 310326.

Topper, T.P., Skovsted, C.B., Harper, D.A.T. \& Ahlberg, P. (2013): A bradoriid and brachiopod dominated shelly fauna from the Furongian (Cambrian) of Västergötland, Sweden. - Journal of Paleontology, 87: 69-83.

Williams, M., Siveter, D.J., Popov, L. \& Vannier, J.M.C. (2007): Biogeography and affinities of the bradoriid arthropods: Cosmopolitan microbenthos of the Cambrian seas. - Palaeogeography, Palaeoclimatology, Palaeoecology, 248: 202-232.

WronA, R. (2009): Early Cambrian bradoriidae and phosphatocopide arthropods from King George Island, West Antarctica. - Polish Polar Research, 30: 347-377.

Zhang, H.Q., Dong, X.-P. \& MAas, A. (2010): Hesslandona angustata (Phosphatocopida, Crustacea) from the Upper Cambrian of western Hunan, South China, with comments on phosphatocopid phylogeny. - Neues Jahrbuch für Geologie und Paläontologie, Abhandlungen, 259: 157-175.

Zhang, H.Q., Dong, X.-P., Waloszek, D. \& MaAs, A. (2016): An orthonauplius of 'Orsten'-type preservation from the Upper Cambrian (Furongian) of South China. - Neues Jahrbuch für Geologie und Paläontologie, Abhandlungen, 279: 175-183.

Zhang, H.Q., Dong, X.-P. \& XIAO, S. (2014): New bivalved arthropods from the Cambrian (Series 3, Drumian Stage) of western Hunan, South China. - Acta Geologica Sinica, 88: 1388-1396.

Zhang, H.Q., XiaO, S., Liu, Y.H., Yuan, X.L., Wan, B., MusCente, A.D., Shao, T.Q., Gong, H. \& Cao, G. (2015): Armored kinorhynch-like scalidophoran animals from the early Cambrian. - Scientific Reports, 5: 16521.

ZhANG, X.G. (2007): Phosphatized bradoriids (Arthropoda) from the Cambrian of China. - Palaeontographica, (A), 281: 93-173.

Zhao, F., Caron, J.-B., Bottuer, D.J., Hu, S., Yin, Z. \& Zhu, M. (2014): Diversity and species abundance patterns of the early Cambrian (Series 2, Stage 3) Chengjiang Biota from China. - Paleobiology, 40: 50-69.

Zhао, F., Zhu, M. \& Hu, S. (2010): Community structure and composition of the Cambrian Chengjiang Biota. - Science in China (Earth Sciences), 53: 1784-1799.

Zhu, C.F. \& Dong, X.-P. (2004): Affinities and functional morphology of the Middle Cambrian ornamented tubules from Western Hunan, China. - Progress in Natural Science, 14: 907-911.

Manuscript received: March 9th, 2017.

Revised version accepted by the Stuttgart editor: May 12th, 2017. 


\section{Addresses of the authors:}

Huaqiao Zhang (corresponding author), State Key Laboratory of Palaeobiology and Stratigraphy, Nanjing Institute of Geology and Palaeontology, Chinese Academy of Sciences, Nanjing 210008, China;

e-mail: hqzhang@nigpas.ac.cn

Shuhai Xiao, Department of Geosciences, Virginia Tech, Blacksburg, Virginia 24061, USA. 